\title{
EFFECT OF P-FERTILIZER AND MICRONUTRIENT (Fe AND Mo) ON SEEDS YIELD OF SOYBEAN AND ITS QUALITY UNDER SANDY SOIL CONDITION
}

\author{
Sahar M. Zakaria \\ Soils, Water and Environ. Res., Inst., Agric. Res. Center, Giza, Egypt \\ Received: May . 31, 2017 \\ Accepted: Jul. 2, 2017
}

\begin{abstract}
A two field experiments were carried out during the two successive growing summer seasons of 2013 and 2014 in sandy soil at El-Sharawy Village , EL-Bostan areaNoubaria Region, Elbeheira Governorate (Latitude 30 43' 22.01" N, Longitude 30 16' 44.50" E) to study the effect of spraying aqueous solutions of iron $(\mathrm{Fe})$ at $20 \mathrm{mg} \mathrm{L}^{-1}$ and seed treatment with Mo at $0.5 \mathrm{~g} \mathrm{~kg}^{-1}$ seeds and three levels of phosphorus $\left(0,15 \mathrm{and} 30 \mathrm{~kg} \mathrm{P}_{2} \mathrm{O}_{5} / \mathrm{fed}\right.$ ) as single super phosphate on seeds yield and yield components of soybean (Glycine max L.), c.v. Giza 111. The experiment was laid out in split plot design with three replications. Yield and yield components as well as chemical composition of soybean seeds were significantly increased by application of P-levels or micronutrient. The result revealed that combined use of seed treatment with molybdenum $(0.5 \mathrm{~g} / \mathrm{kg}$ seed) with foliar spray of iron $(\mathrm{Fe})$ significantly enhanced the growth and yield attributes of soybean and registered $23.59 \%$ and $21.59 \%$ improvement in number of pod and pod weight /plant respectively over control. Results indicated that iron and molybdenum had a significant effect on the increase of weight of pods/ plants (g), weight of 100seed $(g)$, seed and biological yields (ton/fed.). The highest seed weight by $56.25 \%$ over control, also the highest values of seed nitrogen and seed protein content were recorded by combined application of $30 \mathrm{~kg} \mathrm{P}_{2} \mathrm{O}_{5} \mathrm{fed}^{1}+\mathrm{Mo}+\mathrm{Fe}$. The interaction between Mo and Fe combined with Plevels had significant effect on the increase of seed yield / fed and weight of seeds/plant and protein yield/fed. The highest values were recorded when soybean plants were spraying with $\mathrm{Fe}$ and seed treatment with $\mathrm{Mo}$ and treated with $30 \mathrm{~kg} \mathrm{P}_{2} \mathrm{O}_{5} \mathrm{fed}^{1}$.
\end{abstract}

Key words: Soybean plants, spraying with Fe, Seed treatment with Mo, P-levels, Yield and Yield components and Sandy soil

\section{INTRODUCTION}

Soybean (Glycine max L.), is the most important pulse crop in the world. The magnitude of soybean yield losses due to nutrient deficiency also varies among the nutrients. Deficiencies of $\mathrm{N}, \mathrm{P}, \mathrm{Fe}, \mathrm{B}$ and $\mathrm{S}$ may cause soybean yield losses up to $10 \%$, $29-45 \%, 22-90 \%, 100 \%$ and $16-30 \%$, respectively, depending on soil fertility, climate and plant factors. Soybeans (Glycine max L.) serve as one of the most valuable crops in the world, not only as an oil seed crop and feed for livestock and aquaculture, but also as a good source of protein for the human diet and as a biofuel feedstock. World soybean production increased by 4.6 $\%$ annually from 1961 to 2007 and reached average annual production of 217. 6 million metric tons in 2005-07. World production of soybeans is predicted to increase by $2.2 \%$ annually to 371 . 3 million metric tons by 2030 using an exponential smoothing model with a dampened trend (Masuda and Goldsmith, 2009). Soybean oil is used directly in food and preventing high blood pressure caused by arteriosclerosis. It also contains lot of the essential vitamins for the body. Soybean cultivation in Egypt started in 1976. Soybean production in Egypt has increased to about 966 ha. Yield levels have stabilized at about 2895 metric ton per hectare (El -Agroudy et al., 2011).

Phosphorus $(P)$ is essential macronutrient for plant growth and function. The requirements of host plants for optimal growth and symbiotic dinitrogen fixation 
processes for $\mathrm{P}$ have been assessed by determination of nodule development and functioning (Sa and Israel, 1991). The influence of $P$ on symbiotic nitrogen fixation in leguminous plants has received considerable attention, but its role in the process remains still unclear. Robson and O'Hara (1981), concluded that $P$ nutrition increased symbiotic nitrogen fixation in subterranean clover (Trifolium subterraneum L.) by stimulating host plant growth rather than by exerting specific effects on rhizobia growth or on nodule formation and function. The increase of whole plant growth and plant nitrogen concentration in response to increased soil $P$ supply have been noted for several leguminous species including soybean. Decreased specific- nitrogenase activity in nodules of $\mathrm{P}$ - deficient soybean plants was associated with decreased energy status of host plant cells of nodules. These latter observations imply specific involvement of phosphorus in symbiotic nitrogen fixation. However, the conversion of inorganic $P$ into different forms of organic $P$ is not known, especially concerning the formation and functioning of symbiotic nodules.

Metal such as iron is very important for normal growth of soybean (Fageria, 2007). It also plays an important role in the formation of some nodule proteins like nitrogenase and leghaemoglobin (Moran et al., 1997). Iron is necessary for plant growth because of its participation in most important metabolic processes such as ribonucleotides and molecular nitrogen reduction, and energy yielding electron transfer reactions of respiration and photosynthesis (Guerinot and Yie, 1994). Iron deficiency in soybean results in chlorosis (Rotaru and Sinclair, 2009). It was assumed that a single unit increase in chlorosis score resulted in $20 \%$ yield losses in soybean (Froehlich and Fehr, 1981). Similarly molybdenum plays a role as a co-factor of proteins, responsible for electron transfer in synthesis of nitrogenase enzyme and conversion of $\mathrm{N}_{2}$ into ammonia in nitrogen fixation process (Martens and
Westermann, 1991). Deficiency of molybdenum reduces chlorophyll content in soybean and corn (Liu and Yang, 2003). Along with iron and molybdenum, is an essential element for legume crops because it is utilized by micro-organisms for the process of atmospheric nitrogen fixation. Growth processes such as coleoptiles and stem elongation, bud development, leaf disc expansion and opening of hypocotyl hooks are enhanced by iron and molybdenum application in soybean.

The present investigation was carried out to study the effect of both individual and combined treatments of $\mathrm{P}, \mathrm{Fe}$ and $\mathrm{Mo}$ on soybean seed yield, yield component and its quality and seeds content of some macro and micro nutrients under sandy soil conditions.

\section{MATERIALS AND METHODS}

A two field experiments were carried out during the two successive growing summer seasons of 2013 and 2014 in sandy soil at El-Sharawy Village , EL-Bostan area, Noubaria Region, Elbeheira Governorate (Latitude $30^{\circ} 43^{\prime} 22.01^{\prime \prime} \mathrm{N}$, Longitude 30 $16^{\prime}$ $44.50 " \mathrm{E})$ to study the effect of spraying aqueous solutions of iron at $\left(20 \mathrm{mg} \mathrm{L}^{-1}\right)$ and seed treatment with Mo at $0.5 \mathrm{~g} \mathrm{~kg}^{-1}$ seeds, and without and with $\mathrm{p}$ - fertilizer ( 0 , 15and $30 \mathrm{~kg} \mathrm{P}_{2} \mathrm{O}_{5} / \mathrm{fed}$ ) treatments on yield and yield components of soybean (Glycine max L.), c.v. Giza 111 and also its content of some macro and micro nutrients. Before sowing, the seeds were inoculated with $\mathrm{N}_{2}$ fixing bacteria (Brady rhizobium japonicum), at the rate of inoculum $4 \mathrm{~g} \mathrm{~kg}^{-1}$ of seed. The physical and chemical properties of the tested soil sample were collected from the surface layer $(0-20 \mathrm{~cm}) \quad$ Klute (1986) and the obtained data are determined according to Jackson (1973) as shown in Table (1). The experiment was laid out in split plot design with three replications. Each experiment included 12 treatments which were the combination of three levels of phosphorus $\left(0,15\right.$ and $\left.30 \mathrm{~kg} \mathrm{P}_{2} \mathrm{O}_{5} / \mathrm{fed}\right)$ as 
single super phosphate $\left(15.5 \quad \mathrm{P}_{2} \mathrm{O}_{5}\right)$, and four treatments of [control $\left(\mathrm{S}_{0}\right)$, foliar spray with $\mathrm{Fe}$ at $20 \mathrm{mg} \mathrm{I}^{-1}(\mathrm{~S} 1)$, seed treatment with $\mathrm{Mo}$ at $0.5 \mathrm{~g} \mathrm{~kg}^{1}$ seed (S2) and combined treatments of $\mathrm{S} 1$ and $\mathrm{S} 2$ (S3). With respect to foliar treatments, iron $(20 \mathrm{mg}$ $\mathrm{L}^{-1}$ ) . Fe fertilizer Fe-chelate (EDDHA Fe 6\% chelated) was used as foliar spray in two periods (beginning flower) and (beginning pod) stages. Spraying solution treatment was $200 \mathrm{~L} / \mathrm{fed}$., while control plants were sprayed with water. On the other hand, Mo applications used in the seed treatments were used as ammonium molybdate $\left(\mathrm{NH}_{4} \mathrm{Mo}_{7} \mathrm{O}_{24}, 4 \mathrm{H} 2 \mathrm{O}\right)$.

The soybean seeds of the c.v. Giza 111 were soaked in molybdenum solution for half an hour and dried under shade before sowing.

\section{- Experimental design}

A split plot design with three replicates was used. The main plots were assigned to the treatments of phosphorus at three levels while four treatments i.e. [control $\left(\mathrm{S}_{0}\right)$, foliar spray with $\mathrm{Fe}$ at $20 \mathrm{mg} \mathrm{L}^{-1}\left(\mathrm{~S}_{1}\right)$, seed treatment with $\mathrm{Mo}$ at $0.5 \mathrm{~g} \mathrm{~kg}^{1}$ seed $\left(\mathrm{S}_{2}\right)$, and combined treatments of S1 and S2(S3) were randomly distributed in the sub plots. The sub plot area was $1 / 400$ fed., $10.5 \mathrm{~m}^{2}$ $(3 \times 3.5 \mathrm{~m})$ with five ridges which were $60 \mathrm{~cm}$ width and $3.5 \mathrm{~m}$ long. Soybean seeds "Giza

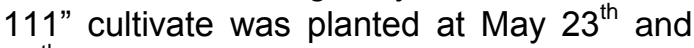
$25^{\text {th }}$ in 2013 and 2014 seasons, respectively. The distance between hills was $10 \mathrm{~cm}$ apart and soybean plants were thinned to two plants per hill. Nitrogen fertilizer was applied in form of ammonium nitrate $(33.5 \%)$ at a rate of $30 \mathrm{~kg} \mathrm{~N} / \mathrm{fed}$ in two equal doses before the first and second irrigations. Also, potassium sulphate $\left(48 \% \mathrm{~K}_{2} \mathrm{O}\right)$ was applied as potassium fertilizer at rate of $50 \mathrm{~kg} \mathrm{~K}{ }_{2} \mathrm{O}$ /fed.in two doses at the same time of $\mathrm{N}$ fertilizer applications. Agronomic practices were followed according to the standard recommendation for soybean.

\section{- Yield and its components}

At harvest, five plants were taken at random from each subplot to determine the yield components, i.e. no. of pods/ plant, weight of pods/ plants $(\mathrm{g})$, weight of seeds/ plant (g) and weight of 100- seed (g). The seed and biological yields of soybean were determined for each plot in three replications. Total nitrogen, phosphorus and potassium contents digests were determined according to the method described by A.O.A.C (1985), A.P.H.A. (1992) and Cottenie et al., (1982), respectively. Also, iron and molybdenum were determined calorimetrically using atomic absorption spectro-photometer according to Jackson (1973). Total nitrogen and oil content were estimated in soybean seeds according to A.O.A.C. (1985). A portion of soybean was taken from each replicate, weighted, airdried, oven -dried at $70^{\circ} \mathrm{C}$ for $48 \mathrm{hrs}$ weighted, ground and kept. A0.5 g of ovendried seeds was taken and digested in of 5 $\mathrm{ml}$ mixture concentrated $\mathrm{H} 2 \mathrm{SO} 4$ and $\mathrm{HClO}_{4}$ (3:1) according to the methods described by Chappman and Pratt (1961). Protein and oil yields $(\mathrm{Kg} / \mathrm{fed})$ were calculated by multiplying protein and oil percentage in seeds by the seed yield /fed.

Table (1): Physical and chemical properties of the soils under investigation (average of two seasons).

\begin{tabular}{|c|c|c|c|c|c|c|c|c|c|c|c|c|}
\hline \multicolumn{5}{|c|}{ Particle size distribution } & \multirow{2}{*}{\multicolumn{2}{|c|}{$\begin{array}{l}\text { OM } \\
(\%)\end{array}$}} & \multirow{2}{*}{\multicolumn{2}{|c|}{$\begin{array}{c}\mathrm{CaCO}_{3} \\
(\%)\end{array}$}} & \multirow{2}{*}{\multicolumn{2}{|c|}{$\begin{array}{c}\text { PH } \\
\text { Soil :water } \\
(1: 2.5) \text { susp }\end{array}$}} & \multirow{2}{*}{\multicolumn{2}{|c|}{$\begin{array}{c}\mathrm{EC}_{\mathrm{e}} \\
\left(\mathrm{dS} \mathrm{m}^{-1}\right)\end{array}$}} \\
\hline $\begin{array}{c}\text { Coarse } \\
\text { sand } \\
\%\end{array}$ & $\begin{array}{l}\text { Fine } \\
\text { sand } \\
\%\end{array}$ & $\begin{array}{l}\text { Silt } \\
\%\end{array}$ & $\begin{array}{c}\text { Clay } \\
\%\end{array}$ & $\begin{array}{l}\text { Texture } \\
\text { class }\end{array}$ & & & & & & & & \\
\hline 52.2 & 39.3 & 5.4 & 3.1 & Sand & & & 3.5 & & 8.1 & & 4.1 & \\
\hline \multicolumn{8}{|c|}{ Soluble cations and anions in the soil paste extract, (meq /L) } & \multicolumn{5}{|c|}{$\begin{array}{l}\text { Available nutrients } \\
\left(\mathrm{mg} \mathrm{kg}^{-1}\right)\end{array}$} \\
\hline \multicolumn{4}{|c|}{ Cations } & \multicolumn{4}{|c|}{ Anions } & \multirow[b]{2}{*}{$\mathrm{N}$} & \multirow[b]{2}{*}{$\mathrm{P}$} & \multirow[b]{2}{*}{$\mathrm{K}$} & \multirow[b]{2}{*}{$\mathrm{Zn}$} & \multirow[b]{2}{*}{$\mathrm{Fe}$} \\
\hline $\mathrm{Ca}^{+2}$ & $\mathrm{Mg}^{+2}$ & $\mathrm{Na}^{+}$ & $\mathrm{K}^{+}$ & $\mathrm{CO}_{3}^{-2}$ & $\mathrm{HCO}_{3}$ & $\mathrm{Cl}^{-}$ & $\mathrm{SO}_{4}^{-2}$ & & & & & \\
\hline 16.1 & 12.8 & 10.2 & 1.8 & & 15.3 & 19.2 & 6.4 & 15 & 6.5 & 85 & 0.7 & 3.1 \\
\hline
\end{tabular}




\section{- Statistical analysis}

Statistical analysis was carried out according to Snedecor and Cochran (1989). The differences between the mean values of various treatments were compared by Duncan's $m$ Results and Discussion ultiple range test (Duncan, 1955).

\section{RESULTS AND DISCUSSION Effect of phosphorus levels on yield attributes and yield}

Application of different levels of phosphorus individually significantly increased yield attributing characteristics of soybean like number of pods plant ${ }^{-1}$, pod weight/plant, seed yield ( $\mathrm{g} /$ plant), weight of 100-seed(g), seed yield (ton/fed.) and biological yield (ton/fed) (Table 2). Application of phosphorus at $30 \mathrm{~kg} \mathrm{P}_{2} \mathrm{O}_{5}$ fed 1 produced high number of pods plant ${ }^{-1}$ (38), seed yield (g/plant) (10.12g) and hundred seed weight $(13.50 \mathrm{~g})$ and the lowest was obtained from the control. Hernandez and Cuevas (2003) reported significant high number of seeds was recorded when $40 \mathrm{~kg} \mathrm{P}_{2} \mathrm{O}_{5}$ fed. $^{-1}$ was applied and minimum number of seeds pod $^{-1}$ when no phosphorus was applied. Significantly seeds and stover yield of soybean was also increased with increasing level of phosphorus fertilizer. The high seed yield (1.02 ton fed $\left.{ }^{-1}\right)$ produced by the application individual of $30 \mathrm{~kg} \mathrm{P}_{2} \mathrm{O}_{5}$ fed $^{-1}$. The increase in seed yield might be due to more number of pods plant ${ }^{-1}$, seeds pod $^{-1}$ and/or hundred seed weight. The low yield of soybean seed was recorded in no phosphorus application treatment. As it is known, phosphorus is involved in several energy transformation processes and biochemical reactions including nitrogen fixation. Root development, stalk and stem strength, and nitrogen fixation in legumes are attributes associated with phosphorus nutrition. It shows that phosphorus is needed in relatively large amounts by legumes for growth and nitrogen fixation and has been reported to promote biomass yield, nodule number, nodule mass etc., in a number of leguminous crops (Kashurikrishna and Aulawat, 1999). Application of different doses of phosphorus caused significant variation in biological yield of soybean (Table, 2). The highest biological yield of soybean (2.68ton $\mathrm{fed}^{-1}$ ) was recorded with $\mathrm{P}_{2}$ treatment of $\left(30 \mathrm{~kg} \mathrm{P} \mathrm{fed}^{-1}\right)$. On the other hand, the lowest biological yield (2.01ton $\mathrm{fed}^{-1}$ ) was recorded in the control treatment.

\section{Effect of seed treatment with molybdenum and foliar application of iron}

The results in Table (2) revealed that seed treatment with molybdenum or foliar application of iron exhibited superior performance over untreated control and the combined seed treatment with molybdenum and foliar application of iron emerged as best and recorded the maximum number of pods plant $^{-1}$, seed yield (g/plant) and hundred seed weight and the lowest was obtained from the control. Molybdenum is an essential trace element and is vital for synthesis and activity of molybdoenzymes such as nitrogen assimilation enzyme-nitrate reductase and the nitrogen fixing enzymenitrogenase, the key regulatory component for initiation of nodulation and maintenance of nitrogen fixation in legumes (Franco and Munns, 1981). Kothari (2002) stated that seed treatment of molybdenum can effectively supplement internal molybdenum deficiencies and rescue the activity of molybdoenzymes. Sable et al. (2000) reported significant influence of seed inoculation with Rhizobium and molybdenum on soybean roots growth and yield. Subasinghe et al. (2003) registered enhanced cowpea growth and nodulation with molybdenum containing micronutrients and Rhizobium inoculation. The favorable effect of $\mathrm{Fe}$ or Mo on yield and yield components may be attributed to their effect on growth parameters, which in turn improve yield and yield components. Confirming results were reported by El- Mansi et al. 


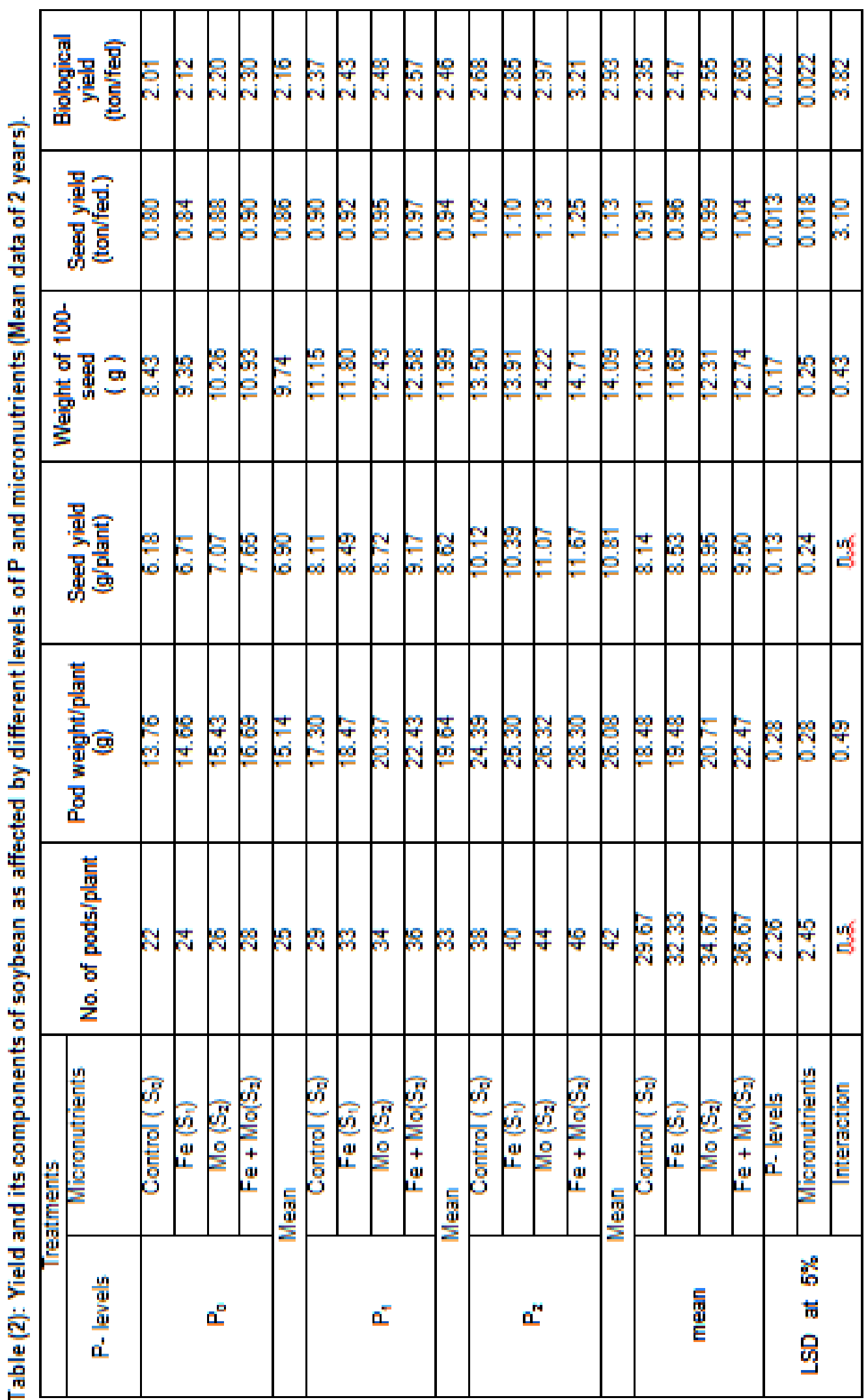


(2000), Nassar et al. (2000 a \& b) and Ahmed et al. (2001). Similarly the significant increase in thousand seed weight (Table, 2) can also be attributed to $\mathrm{Fe}$ and $\mathrm{Mo}$ application as both are the important components of enzyme nitrogenase and nitrate reductase that enhance bacterial growth and symbiotic efficiency resulting in improved plant growth and yield (Solaiman, 1999). These results favors the findings of Rahman et al. (2008) and Heidarian et al. (2011). Combined seed treatment with molybdenum and foliar application of iron favorably influenced the plant vigor, morphology and metabolic processes, which ultimately enhanced the pods per plant and total yield of soybean. The favorable effect of $\mathrm{Fe}$ or Mo on yield and yield components may be attributed to their effect on growth parameters, which in turn improve yield and yield components.

\section{Interaction of $\mathrm{P}, \mathrm{Fe}$ and $\mathrm{Mo}$}

Results of interaction between seed treatment with molybdenum and foliar application of iron and combined with different levels of phosphorus presented in Table (2) showed significant increase on pod weight/plant (g), weight of 100-seed (g), seed yield ton/fed.) and biological yield (ton/fed) . Their maximum by inculating soybean seeds with Mo at $0.5 \mathrm{~g} \mathrm{~kg}^{-1}$ seeds or spraying the plants by $\mathrm{Fe}$ at $20 \mathrm{mg} \mathrm{L}^{-1}$ with $30 \mathrm{~kg} \mathrm{P}_{2} \mathrm{O}_{5}$ fed $^{-1}$ treatment, whereas the lowest values for these traits were obtained by untreated plants (control treatments). Combined seed treatment with molybdenum and foliar spray of iron showed synergistic effect and resulted in improvement of morphological traits of soybean pod weight/plant (g), weight of 100-seed (g), seed yield ton/fed.) and biological yield (ton/fed). These results are in harmony with those recorded by Amara and Nasr (1995).

\section{Effect of phosphorus levels on oil and protein content and yield}

Oil content (\%) of soybean seed as shown in Table (3) increased with increasing levels of phosphorus fertilizer this respect similar results were obtained by (Prasad, et al. 1991). Similarly oil yield was also increased in the same trend. This might be due to higher oil content as well as higher seed yield. Similar finding was also reported by Tomar, et al. (2004) who observed that phosphorus application increased oil contents of soybean. Bardan (2003) also reported that more oil yield was produced when higher doses of phosphorus applications. Apart from other factors, quality of crop depends upon the protein content of seed, which is the major constituent of seed in legumes. The high seed protein content $(31.87 \%)$ was achieved by using $30 \mathrm{~kg} \mathrm{P}_{2} \mathrm{O}_{5}$ $\mathrm{fed}^{-1}($ Table, 3). On the other hand the lowest protein content $(24.12 \%)$ was observed from control. In the same trend protein yield $\left(\mathrm{kg} / \mathrm{fed}\right.$.) was also higher $\left(325.95 \mathrm{~kg} \mathrm{fed}^{-1}\right)$ when using $30 \mathrm{~kg} \mathrm{P}_{2} \mathrm{O}_{5}$ fed $^{-1}$ and the lowest $\left(194.04 \mathrm{~kg} \mathrm{fed}^{-1}\right)$ was obtained from the control (Table, 3).

\section{Effect of micronutrients on oil and protein content and its yield}

Results in Table (3) indicate that seed treatment with molybdenum and foliar application of iron had significant effect on the increase of protein and oil yield/fed as compared to control treatment. Iron is required for several key enzymes of the nitrogenase complex as well as for the electron carrier ferredoxin and for some hydrogenases. A particular high iron requirement exists in legumes for the heme component of hemoglobin. Also, the results revealed that seed treatment with molybdenum exhibited superior performance over untreated control. Molybdenum plays a role as a co-factor of proteins, responsible for electron transfer in synthesis of nitrogenase enzyme and conversion of $\mathrm{N}_{2}$ into ammonia in nitrogen fixation process (Martens and Westermann, 1991).Deficiency of molybdenum reduces chlorophyll content in soybean and corn (Liu and Yang, 2003). Likewise the lowest seed protein content $(28.06 \%)$ was recorded in control $\left(\mathrm{S}_{0}\right)$ while 
产要

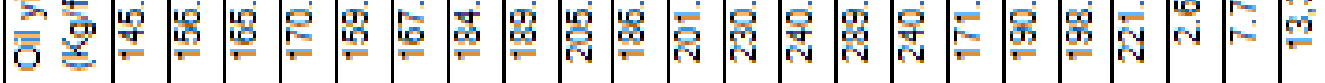

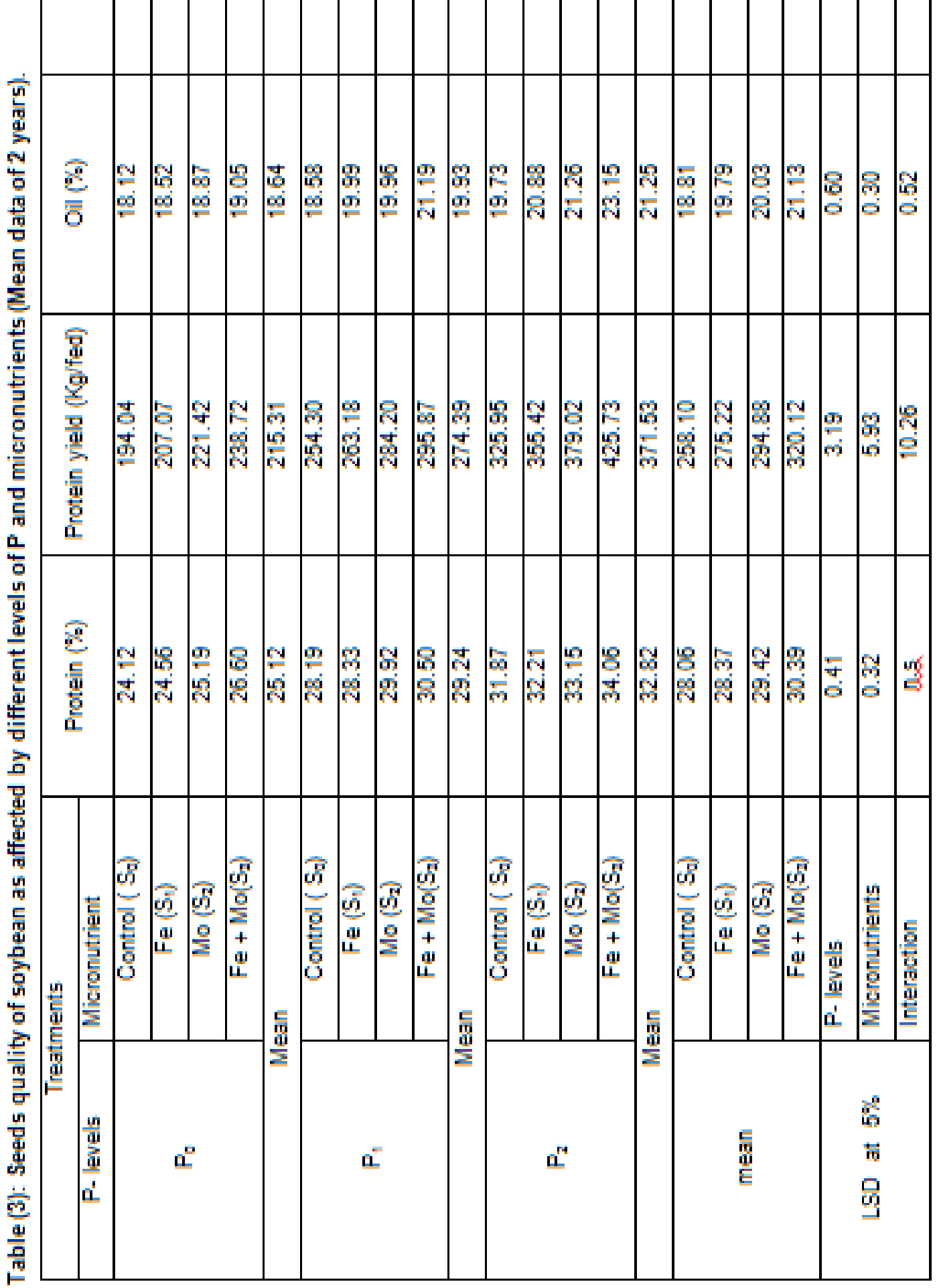


the highest seed protein content $(30.39 \%)$ was noted in $\mathrm{Fe}+\mathrm{Mo}\left(\mathrm{S}_{3}\right)$. The significant increase in seed protein content can be attributed to Mo, and $\mathrm{Fe}$ application, as Mo take a part in increasing photosynthetic rates (Liu and Yang, 2003; Sun et al., 2006). Along with $\mathrm{Fe}$ and $\mathrm{Mo}$, significantly improved photosynthesis activity that contributed for overall plant growth, mineral content and yield (Caliskan et al., 2008 and Campo et al., 2009).

\section{Interaction of $\mathbf{P}$ and micronutrients}

The result indicated a significant interaction between seed treatment with molybdenum and foliar application of iron and combined with levels of phosphorus (Table, 3 and Figure, 1). Combined use of seed treatment with molybdenum and foliar application of iron along with phosphorus $\left(\mathrm{P}_{2} \mathrm{~S}_{3}\right)$ showed significant effect on the increase of protein yield/fed as well as oil yield $(\mathrm{kg} / \mathrm{fed})$ reaching their maximum by spraying soybean plants with $\mathrm{Fe}$ at $20 \mathrm{mg} \mathrm{L}$ 1 and seed treatment with molybdenum at $0.5 \mathrm{~g} \mathrm{~kg}^{-1}$ seeds with $30 \mathrm{~kg} \mathrm{P}_{2} \mathrm{O}_{5} \mathrm{fed}^{-1}$ treatment, whereas the lowest values for these traits were obtained by untreated plants (control treatments). These results are in harmony with those recorded by Amara and Nasr (1995).

\section{Effect of phosphorus levels on nutrients uptake}

Data presented in Table (4) reveal that total uptake of nutrients by seeds of soybean increased with increasing levels of phosphorus compared to control treatment. The result revealed that, the phosphorus treatments had significant effects on the uptake of nutrients by seeds of soybean. Maximum phosphorus uptake was obtained from $30 \mathrm{~kg} \mathrm{P}_{2} \mathrm{O}_{5}$ fed $^{-1}$ and the lowest was obtained from the control. Phosphorus plays an important role in the plant's root development, facilitating the earlier formation of nodules, enhancing the activity of Rhizobia, increasing their numbers and enhancing the nitrogen fixation. Kumar and Kushwaha (2006) reported that total uptake of nutrients by pigeon pea significantly increased with increasing phosphorus level due to higher amount of biomass production and subsequently greater phosphorus accumulation by the plant. Shankaralingappa, et al. (2000) also made similar observations.

\section{Effect of micronutrients on nutrient uptake}

Combined seeds treatment with molybdenum and foliar application of iron have a significant effects on the increase of nutrients uptake of $\mathrm{N}, \mathrm{P} \& \mathrm{~K}$ by 9.19 \& $16.56 \%, 9.81 \& 19.27 \%$ and 10.65 and $13.80 \%$ over the individual treatment of seed treatment with molybdenum or foliar application of iron, respectively. Improvement of $\mathrm{N}, \mathrm{P}$ and $\mathrm{K}$ uptake with $\mathrm{Fe}+$ Mo $\left(\mathrm{S}_{3}\right)$ was noticed of $24.23,28.92$ and 22.89 per cent over control. Also, the results revealed that micronutrient application through seed treatment with molybdenum and foliar application of iron significantly increased the $\mathrm{Fe}(2.35$ and $2.74 \%)$ and $\mathrm{Mo}$ (10.00 and $46.67 \%$ ) content in soybean over individual micronutrient application. Result show that $\mathrm{Fe}$ and Mo content were also increased by 12.70 and $83.33 \%$ with $\mathrm{Fe}+$ Mo $\left(\mathrm{S}_{3}\right)$ over control. The improvement in nutrient status with seed treatment with molybdenum as well as foliar application of iron seems to be on account of higher dry matter accumulation as well as nutrient status. The beneficial role of micronutrient in increasing the cation exchange capacity of root helped in the increased absorption of nutrients from the soil. Further, the beneficial role of micronutrient in chlorophyll formation, regulating the auxin concentration and its simulatory effect on most of physiological and metabolic processes of the plant might have helped the plants in absorption of greater amount of nutrients from soil. Our results are in concurrence with the findings of Singh and Kumar (2011).

\section{Interaction of $P$ and micronutrients}

The result indicated a significant interaction between seed treatment with molybdenum and foliar application of iron and combined with levels of phosphorus (Table, 4 and Figure 2). Combined use of seed treatment with molybdenum and foliar 


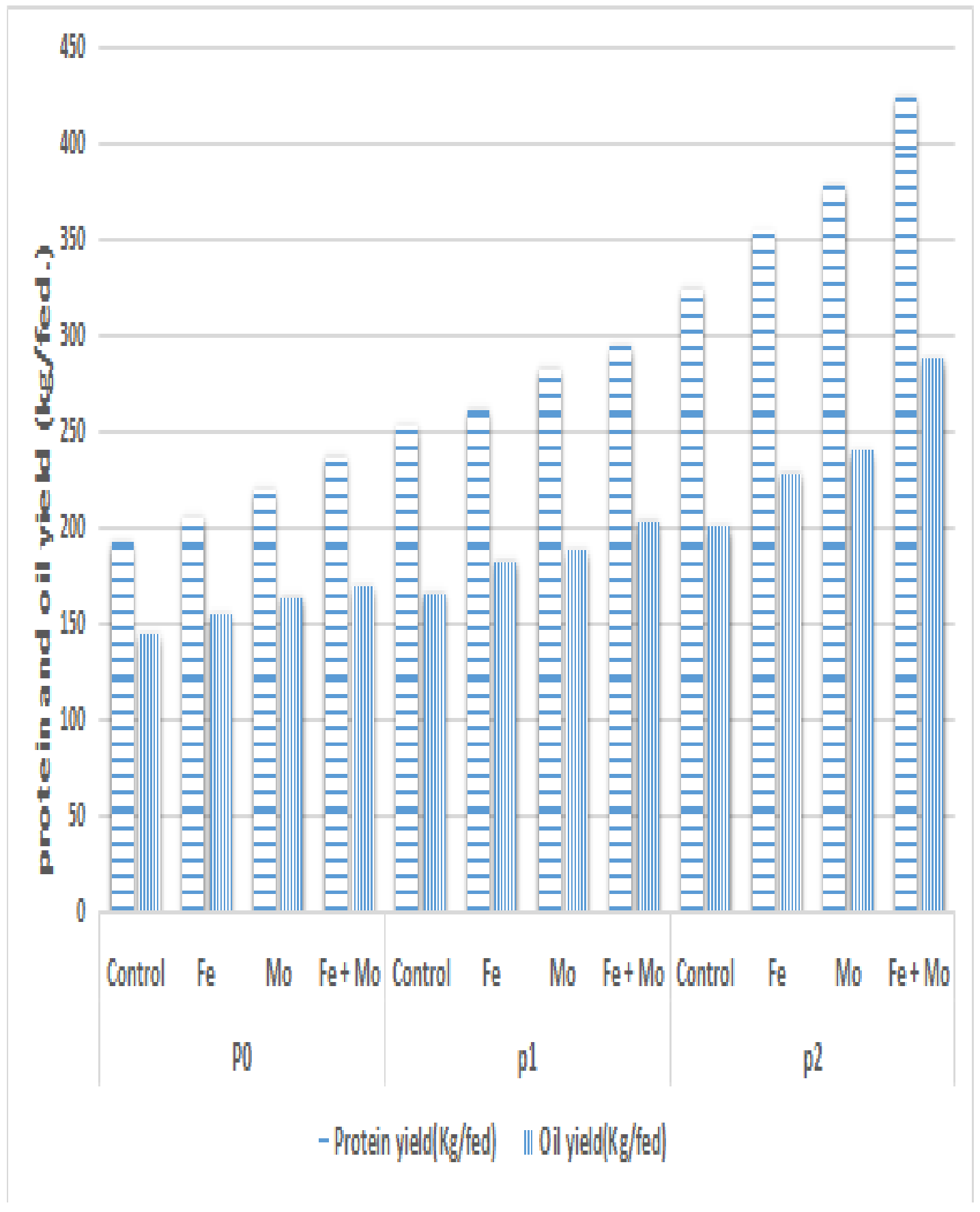

Fig. (1) Seeds quality of soybean as affected by differentlevels of Pand micronutients 


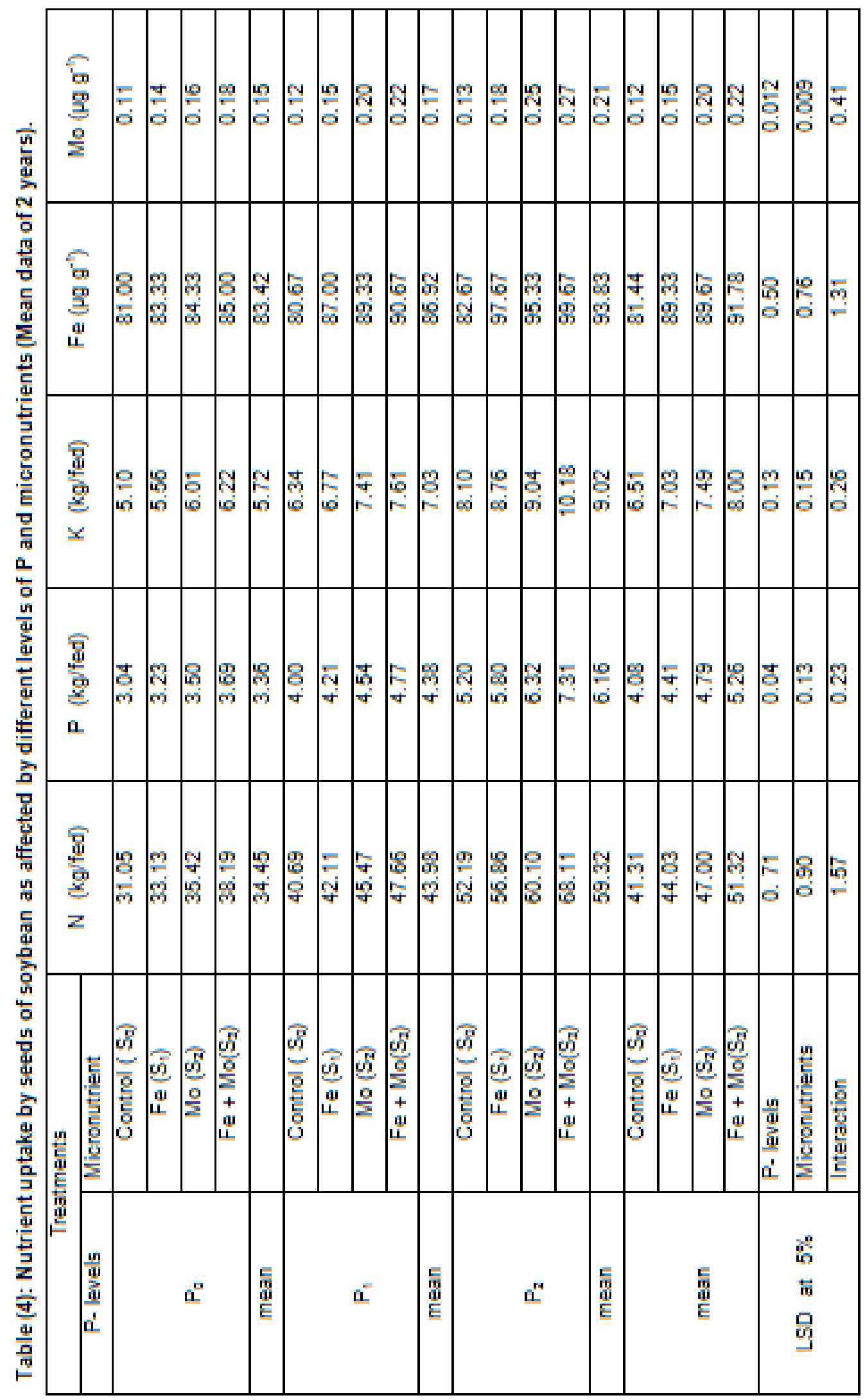




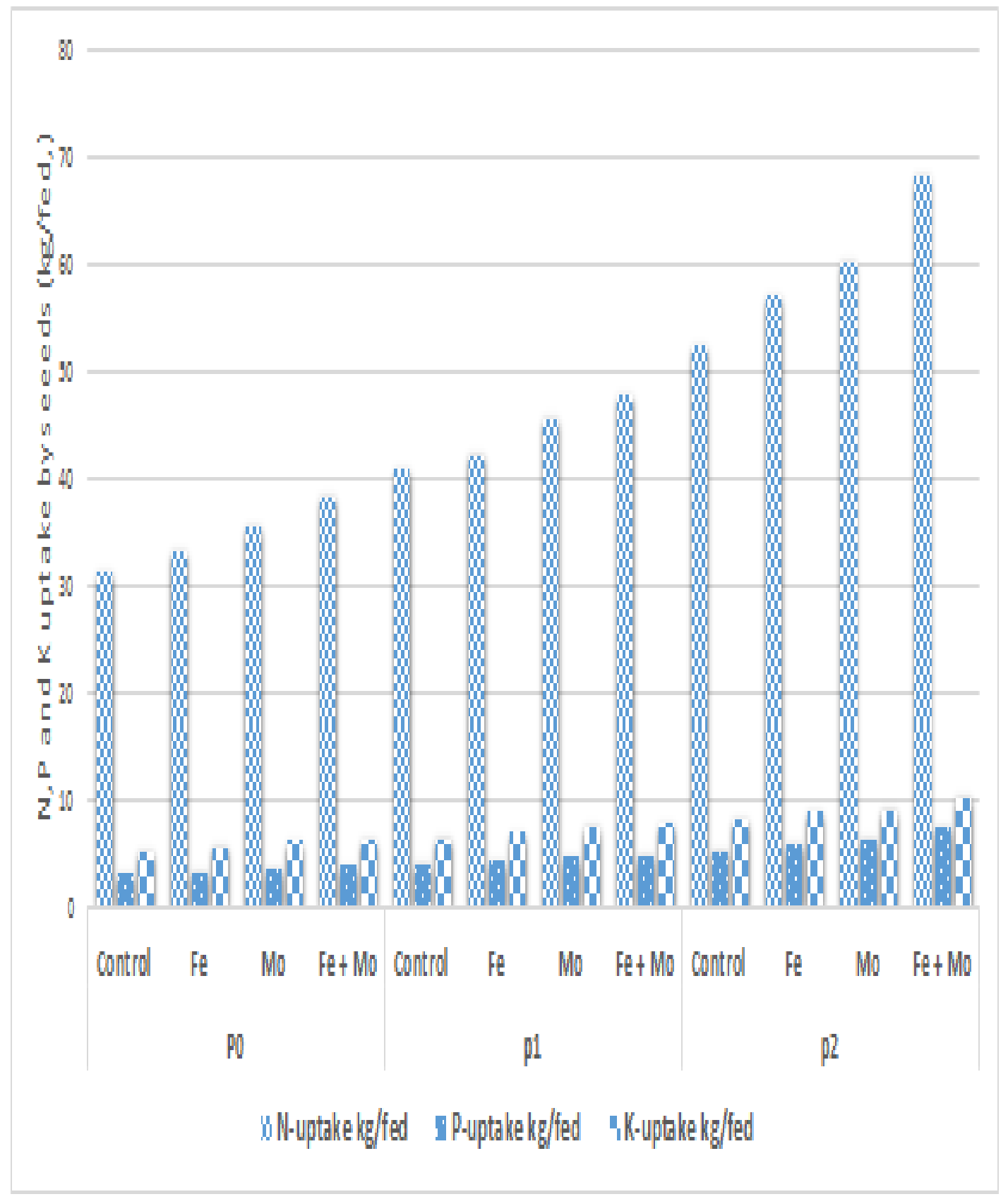

Fig. (2): Nutrient (N., and K) in seeds of soybean as affected by different levels of P and micronutrients 
application of iron along with phosphorus $\left(\mathrm{P}_{2} \mathrm{~S}_{3}\right)$ showed significant effect on the increase of nutrients uptake by seeds. These results are in agreement with those recorded by Shivay (2010).

\section{Conclusion}

Combined use of seed treatment with molybdenum and foliar application of iron as individual in combination with phosphorus $\left(\mathrm{P}_{2} \mathrm{~S}_{3}\right)$ may be recommended for getting higher seeds yield of soybean because of their synergistic effect on yield attributing characters and seed yield. The result concluded also that the seed treatment with molybdenum and foliar application of iron with the (30 $\mathrm{kg} \mathrm{P}_{2} \mathrm{O}_{5} / \mathrm{fed}$.) fertilizer led to good results and often convergent with the results of full fertilization. These results lead to the conclusion that, the addition of molybdenum +iron enhanced soybean yield quantity and quality.

\section{REFERENCE}

Adesoji, A. G., I. U. Abubakar, D. B. Ishaya, (2009). Performance of soybean (Glycine max L.) Merrill as influenced by method and rate of molybdenum application in Samaru, Northern Guinea Savanna of Nigeria. American Eurasian J. Sustain. Agric., 3: 845-849.

Ahmed, S. A., S. A. Saad EL- Din. and I. M. El-Metwally (2001). Influence of some micro-elements and some weed control treatments on growth, yield and its components of soybean plants. Annals of Agric. Sci.; Moshtohor, 39 (2): 805-823.

Amara, Mervat A. and Sohier A. Nasr (1995). Impact of foliar application with bio fertilizers and micronutrients on the growth and yield of Bradyrhizobium inoculated soybean plants. Annals. Agric. Sci. Ain shams Univ. Cairo, 40 (2): 567578.

A.O.A.C., "Association of Official Agricultural Chemists" (1985). Official Methods of Analysis. $12^{\text {th }}$ Ed., Washington D. C., U.S.A.
A.P.H.A., American Public Health Association (1992). Standard Methods for the Examination of Water and Wastewater. Washington, D. C., U.S.A.

Bardan, M. M. (2003). Effect of nitrogenous and phosphetic fertilization on some economical characters of soybean Crawford cultivar under calcareous soil conditions. Egyptian J. Agric. Res., 81(2): 433-440.

Caliskan, S., I. Ozkaya, M. E. Caliskan, M. Arslan, (2008). The effects of nitrogen and iron fertilization on growth, yield and fertilizer use efficiency of soybean in a Mediterranean type soil. Field Crops Res., 108:126-132.

Campo, R. J., R. S. Araujo and M. Hungria (2009). Molybdenum enriched soybean seeds enhance nitrogen accumulation, seed yield and seed protein content in Brazil. Field Crop Res., 110: 219-224.

Chapman, H. D. and P. F. Pratt (1961). Methods of Analysis for soils, plants and water. Univ. California, Berkeley, CA, USA.

Cottenie, A., M. Verloo, L. Kickens, G. Velghe and R. Camerlynck (1982). "Chemical analysis of plants and soils". Lab. Analytical and Agrochem;State Univ., Ghent- Belgium, P. 63.

Duncan, D. B. (1955). Multiple range and multiple F-test.J. Biometrics, 11: 1-42.

El-Agroudy, N., S. Mokhtar, E. Awad-Zaghol and M. El-Gebaly (2011). An economic study of the production of soybean in Egypt. Agric Biol J N Am.; 2(2): 221-225

El-Mansi, A. A., A. Bardisi and S. A. ElAtabany (2000). Effect of plant density, foliar spray with Mo and Vit. $B_{12}$ on nodulation, plant growth and yield of pea under sandy soil conditions. Zagazig J. Agric. Res. 27 (4): 913-929.

Fageria, N. K. (2007). Soil fertility and plant nutrition research under field conditions: Basic principles and methodology. J. Plant Nutr., 30 (2): 203-223.

Franco, A.A. and D.N. Munns (1981). Response of Phaseolus vulgaris $L$. to 
molybdenum under acid conditions. Soil Sci. Soc. Am. J. 45: 1144-1148.

Froehlich, D. M. and W. R. Fehr (1981). Agronomic performance of soybeans with different levels of iron deficiency chlorosis on calcareous soil. Crop Sci., 21: 438-441.

Guerinot, M. L. and Y. Yie (1994). Iron: nutritious, noxious, and not readily available. Plant Physiol., 104: 815-820.

Heidarian, A. R., H. Kord, K. Mostafavi, A. P. Lak and F. A. Mashhadi (2011). Investigating $\mathrm{Fe}$ and $\mathrm{Zn}$ foliar application on yield and its components of soybean (Glycine max L Merr.) at different growth stages. J. Agric. Biotech. Sustain. Dev., 3: 189-197.

Hernandez, M. and F. Cuevas (2003). The effect of inoculating with Arbuscularmycorrhiza and Brady rhizobium strains on soybean (Glycine max L. Merrill) crop development. Cultivos - Tropicales, 24(2): 19-21.

Jackson, M. L. (1973). Soil Chemical Analysis. Prentic-Hall of India, private, New Delhi.

Kashurikrishna, S. and P. S. Ahlawat (1999). Growth and yield response of pea (Pisumsativum) to moisture stress, phosphorus, sulphur and zinc fertilizers. Indian J. Agron., 44: 588-596.

Klute, A. (1986). 'Methods of Soil Analysis". American Society of Agron., Inc. Soil Soc, of Amer., Inc Madison, Wisconsin, U.S.A., $2^{\text {nd }}$ Edition.

Kothari, M.L. (2002). Effect of modes and levels of molybdenum application on grain yield protein content and nodulation of chickpea grown on loamy sand soil. Commun. Soil Sci. Plant Anal. 33 (15): 18-23.

Kumar, Avinash and H. S. Kushwaha (2006). Response of pigeon pea (Cajanuscajan) to sources and levels of phosphorus under rain fed condition. Indian Journal of Agronomy, 51(1): 6062.

Liu, P. and Y. A. Yang, (2003). Effect of molybdenum and boron on photosynthetic efficiency of soybean. Plant Nutr. Fertil. Sci., 9: 456-461

Martens, D. C. and D. T. Westermann (1991). Fertilizers Applications for Correcting Micronutrient Deficiencies. In: Micronutrients in Agriculture $2^{\text {nd }} \mathrm{Ed}$. Mortvedt, J. J., Cox, F. R., Shuman, L. M. and Welch, R. M. (Eds.). Soil Sci. Soc. America. Madison, WI. pp: 90-112.

Masuda, T. and P.D. Goldsmith (2009). World soybean production: area harvested, yield, and long-term projections. International Food and Agribusiness Management Review; 12(4): 143-162.

Moran, J. F., R. V. Klucas, R. J. Grayer, J. Abian and M. Becana (1997). Complexes of iron with phenolic compounds from soybean nodules and other leguminous tissues: prooxidant and antioxidant properties. Free Radic. Biol. Med., 22: 861-870.

Nassar, K., E. A. O. Osman, M. H. EL-khaly and M. M. Badran (2000 a). Effect of seed coating with some micronutrients on fababean (Vicia faba, L.). II Effect on yield, yield attributes and mineral composition. J. Agric. Sci. Mansoura Univ., 25 (11): 7215-7227.

Nassar, K., S. A. Radwan and A. A. Rahmou (2000 b). Effect of seed coating with some micronutrients on fababean (Vicia faba, L.) I. Effect on photosynthetic pigments, micronutrients content and plant growth characters. J. Agric. Sci. Mansoura Univ. 25(11): 7203-7213.

Prasad, F. M., D. S., Sisodla, M. L., Varsheey and M. M. Verma (1991). Effect of different levels of sulphur and phosphorus on growth, dry matter, oil content and uptake of nutrients by soybean. New Agriculturist, 2(1): 15-18.

Rahman, M. M., M. M. H. Bhuiyan, G. N. C., Sutradhar, M. M. Rahman and A. K. Paul (2008). Effect of phosphorus, molybdenum and rhizobium inoculation on yield and yield attributes of mungbean. Int. J. Sustain. Crop Prod., 3: 26-33. 
Robson, A. D. and G. W. O'Hara (1981). Involvement of phosphorus in nitrogen fixation by subterranean clover (Trifolium subterraneum L.). Aust. J. Plant Physiol. 8: $427-436$.

Rotaru, V. and T. R. Sinclair (2009). Influence of plant phosphorus and iron concentrations on growth of soybean. J. Plant Nutr., 32: 1513-1526.

Sa T. M. and D. W. Israel (1991). Energy status and functioning of phosphorusdeficient soybean nodules. Plant Physiol. 97: 928-935.

Sable, S., P.Y. Sontakey, B. Nair, P. Manapure and R.D. Deotale (2000). Influence of seed inoculation with Rhizobium and molybdenum on soybean roots. J. Soils Crops 10 (2): 126-130.

Shankarlingappa, B. C., B. Shivaraj, K. Sudhir and K. P. Vishwanatha (2000). Interaction effect of phosphorus and sulphur on uptake of nitrogen, phosphorus, potassium and by pigeon pea. (Cajanuscajan). Indian Journal of Agronomy, 45(2): 348-352.

Shivay, Y.S. (2010). Importance of micronutrients management for increased crop productivity. Journal of Food Security; 1:42-53.
Singh, S. and A. Kumar (2011). Effect of micronutrient on yield, quality and nutrient uptake by wheat in alluvial soil. Annals of Plant and Soil Research; 13:84-86.

Snedecor, G. W. and W. G. Cochran (1989). Statistical Methods. $8^{\text {th }}$ Ed., lowa State Univ., Press. lowa, U.S.A.

Solaiman, A.R.M. (1999). Response of mungbean to Bradyrhizobium sp. (Vigna) inoculation with and without phosphorus and potassium fertilization. Bangladesh J. Sci. Res. 17(2): 125-132.

Subasinghe, S., G.A. Dayatilake and R. Senaratne (2003). Effect of B, Co and Mo on nodulation, growth and yield of cowpea (Vigna unguiculata L). Trop. Agric. Res. Ext. 6: 108-112.

Sun, X. C., C. X. Hu, Q. L. Tan and Q. Q. Gan (2006). Effects of molybdenum on photosynthetic characteristics in winter wheat under low temperature stress. China. Agric. Sci., 32:1418-1422.

Tomar, S.S., R. Singh and S.P. Singh (2004). Response of phosphorus, sulphur and rhizobium inoculation on growth, yield and quality of soybean (Glycine max L.). Progressive Agriculture 4(1): 72 73. 


\title{
تأثير التسميد الفوسفاتى والمغذيات الصغرى (الحديد والمولبيدنم ) على محصول بذور فول الصويا وجودته تحت ظروف الارض الرملية
}

\author{
سحر محمد زكريا \\ معهد بحوث الاراضى والمياه والبيئة - مركز البحوث الزراعية- جيزة - مصر
}

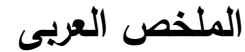

أجريت هذه الدراسة خـال موسمى 2013 و 2014 فى قرية الثعراوى بمنطقة البستان - النوبارية محافظة البحيرة بهدف

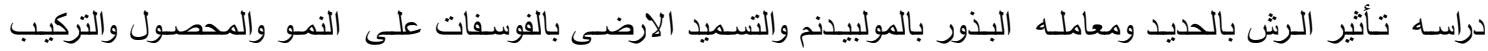

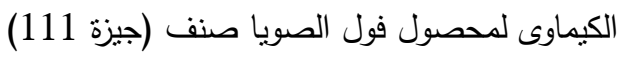
وقد تضمنت الدراسة 12 معامله عبارة عن التوافق بين اربعة معاملات عناصر صغرى وهى ( الرش بالماء ككنترول للمقارنه - الرش بالحديد بتركيز 20 ملجم /لتر - معامله البذور بالمولبيدنم 0.5جم /1كجم بذور - الرش بالحديد معامله البذور بالمولبيدنم ) وثلاث معاملات للنسميد الفوسفاتى وهى (بدون تسميد فوسفاتى ككنترول -15و 30 كجم فوماك للفدان) حيث استخدم التصميم الاحصائى للقطع المنشقة مرة واحدة فى ثناث مكررات وتم دراسه الصفات التالية

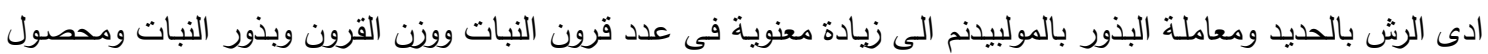
البذور للفدان ومحصول البروتين والزيت فى البذور وذلك مقارنه بمعاملة الكنترول ناثرت كل صفات النمو والمحصول ومكونات المحصول والتركيب الكيماوى للبذور تاثيرا معنويا مع التسميد الفوسفاتى وذلك الثكان مقارنه بمعاملة الكنترول كان للتفاعل بين الرش بالحديد أو معاملة البذور بالمولبيدنم مع التسميد الفوسفاتى تاثيرا معنويا على محصول البذور للفدان

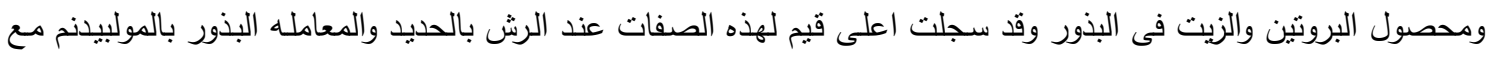

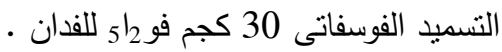

